\title{
Adjacency and Due Regard:
}

\section{The Role of Coastal States in the BBNJ Treaty \\ Joanna Mossop and Clive Schofield}

\section{Abstract}

In the negotiations for the new treaty on biodiversity beyond national jurisdiction (BBNJ), a key question will be the relationship between the regime for areas beyond national jurisdiction (ABNJ) and areas under coastal State jurisdiction. Adjacency has been raised as a concept that might assist in bridging these areas. It has been suggested that adjacency is a legal principle that could give coastal States additional rights or responsibility in relation to biodiversity in $\mathrm{ABNJ}$ proximate to their own national maritime jurisdictions. However, there has never been an acceptance in the law of the sea that coastal States have priority over other States in ABNJ. We propose that due regard is a more appropriate lens to address this issue and one that would be consistent with existing principles under the United Nations Convention on the Law of the Sea (UNCLOS). References to adjacent coastal States can be found in the draft text considered by the Intergovernmental Conference. The article analyses challenges arise in defining adjacent States as well as applying due regard to elements of the package. It considers the use of adjacency in the draft texts issued for the third and fourth sessions of the Intergovernmental Conference, as well as proposals made by delegates.

\section{Keywords}

Adjacency, BBNJ, due regard, marine genetic resources, MGR, environmental impact assessment, area-based management.

\section{Introduction}

Negotiations are underway for a new international legally binding instrument (ILBI) for the conservation and sustainable use of biodiversity beyond national jurisdiction (BBNJ) [1]. Although the focus of the ILBI will be on activities in areas beyond national 
jurisdiction (ABNJ), it seems likely that the treaty will need to address how to manage activities taking place in $\mathrm{ABNJ}$ with connections to, and impacts on, areas within coastal State jurisdiction (AWNJ). A concept that has emerged during the negotiations as a possible response to this challenge is that of "adjacency". One suggested formulation of adjacency is the idea that coastal States should be given "greater influence over management of those ABNJ resources to which they lie adjacent" [2]. This article examines this contention and concludes that there can be no support in the law of the sea for giving coastal States greater rights in relation to $\mathrm{ABNJ}$ that lie close to their coastline. Although this article argues there is no such existing principle of adjacency under the United Nations Convention on the Law of the Sea (UNCLOS), there is nonetheless a good argument that the ILBI could contain provisions clarifying the rights and obligations of all States where activities create impacts that cross the maritime zones of coastal States and $A B N J$. The existing principle of due regard is arguably the best approach to balancing such rights. In some cases the ILBI will need to contain explicit provisions to give due regard practical meaning, and some suggestions are offered for how the relationship could be addressed in the treaty and under each element of the BBNJ package.

This article first addresses the concept of adjacency in the context of the ILBI and other law of the sea instruments. The article then explores how the ILBI might take into account the interests of coastal States in activities occurring in ABNJ, notably through using "due regard" as a general or overarching principle applying to distinct elements of the overall ILBI package. Finally, the article makes some observations on how the interests of adjacent coastal States are reflected in the draft texts issued for the third and fourth sessions of the Intergovernmental Conference (IGC 3 and IGC 4), and how they relate to the principle of due regard.

\section{Adjacency}

\subsection{The development of the adjacency debate}

The relationship between coastal State rights and the rights of States in ABNJ has arisen in several ways during the BBNJ discussions. First, coastal States have been very clear that the obligations in the ILBI must not negatively impact on their rights to explore and exploit the resources of the exclusive economic zone (EEZ) and continental shelf. Because 
the scope of the ILBI is primarily focused on activities conducted in ABNJ, there has been little discussion about the obligations that coastal States have in respect of biodiversity in $\mathrm{ABN} J$, although those obligations do exist [3,4]. Second, a question has emerged about the role that coastal States might play in relation to activities in $\mathrm{ABNJ}$ that might impact on biodiversity found within national jurisdiction. The focus of this article is on this second aspect, as it has generated some debate and confusion among delegations.

One of the areas of apparent confusion has been around the meaning of adjacency. The word "adjacent" has primarily been used as a geographical descriptor denoting proximity in UNCLOS, the United Nations Fish Stocks Agreement (UNFSA), and the draft texts released prior to the IGC 3 and IGC $4[5,6]$. In the context of the negotiations toward an ILBI the word is most often used to signal situations in which a coastal State's AWNJ are physically close to or adjoining parts of the $\mathrm{ABNJ}$ where activities are taking place. In this context, referring to adjacency can simply be a short-hand for the explicit elucidation of the rights or obligations of adjacent coastal States.

A second meaning of adjacency, and one advocated by some commentators and coastal States in the BBNJ discussions, argues that coastal States have a special role, or greater rights, in parts of $\mathrm{ABNJ}$ that are nearby, or ecologically linked, to AWNJ. This understanding of adjacency was most clearly articulated in a Policy Brief released in 2017, which drew attention for its argument that coastal States should have greater influence over the management of the conservation of biodiversity in adjacent areas of ABNJ [2]. The Policy Brief focused on the interconnectivity of ocean ecosystems across jurisdictional boundaries as well as the responsibility that coastal States have to ensure the protection of the marine environment.

The authors argued that adjacent coastal States have a higher interest in ABNJ due to the ecological and cultural connectivity to those parts of the ABNJ that they are adjacent to. Therefore, they proposed that "adjacent coastal States should have the primary responsibility to coordinate with regional and sectoral organisations to become the lead architects of new regional conservation agreements." This potential role was considered to be particularly important for migratory species not regulated by regional fisheries bodies although the brief acknowledged that adjacency could not be used to assert a priority over the exploitation of those species. The authors also argued that adjacency should be seen against the context of the duty of coastal States to "implement 
conservation measures not only within, but beyond their EEZs "and thus "to enforce conservation measures in waters where conditional freedoms apply ... and the Area" [2].

The Policy Brief reflected the views of the Pacific Small Island States group (PSIDS), expressed during the PrepCom and IGC, that the interconnected nature of the high seas and their coastal waters means that they have a particular interest in how the areas adjacent to their maritime zones are managed [7]. However, the calls for adjacency to be included in the ILBI have been resisted by other delegations, concerned about the implication that adjacent coastal States might have a greater interest, or greater rights, in ABNJ than other States [8].

Adjacency has appeared in the official documents of the IGC. A reference to a principle of adjacency, without further explanation, appeared in the President's Aid to Negotiations for the second session of the Intergovernmental Conference (IGC 2). This was criticised by many delegations because it lacked definition and there was concern that it implied the meaning of adjacency advocated in the Policy Brief. A reference to "adjacent States" also appeared multiple times in the lists of options, but in general these references were a strictly geographical descriptor, rather than a use of adjacency suggesting that certain coastal States could have preferential rights in areas of ABNJ immediately abutting parts of their AWNJ.

In the draft text released prior to IGC3, adjacency did not feature as a principle, but the draft text did include a number of provisions on how the interests of adjacent coastal States would be provided for. Indeed, the 17 references to adjacency in the draft text were predominantly confined to a geographical sense of the word such as "adjacent coastal States" ${ }^{1}$

The second draft text released in November 2019 did not substantially alter the way in which adjacency was used. No principle of adjacency was identified or articulated, and again the references to adjacency were geographical in nature. ${ }^{2}$

Arguably the issue of how to deal with activities taking place in ABNJ that impact on the rights of coastal States in AWNJ is one that deserves addressing in the ILBI. A key

\footnotetext{
${ }^{1}$ E.g. articles 11, 17, 18, 19 and 34 of the First Draft Text.

${ }^{2}$ E.g. articles $11,15,17,18,26,34,41$ and 48 of the Second Draft Text.
} 
challenge in this context and for achieving coherent oceans governance more broadly is the inherently connected character of marine ecosystems which do not readily fit the jurisdictional limits, zones and boundaries provided by UNCLOS. This issue is an especially acute consideration where areas of high seas within ABNJ overlie areas of continental shelf that extend beyond 200 nautical mile exclusive economic zone (EEZ) limits - areas that encompass over 37 million $\mathrm{km}^{2}$ [9]. While the coastal State has sovereign rights over sedentary species in these areas in accordance with article 77(4) of UNCLOS, the reality is that many of the species concerned are part of complex benthic ecosystems that span the seabed/water column divide and, indeed, may spend part of their lifecycle in the water column, for instance in larval or juvenile stages, and the remainder on the seabed, thus transcending the ABNJ/AWNJ divide [10,11]. Of even wider significance is that ecosystems can be connected to distant parts of the ocean either passively through ocean currents or actively through the migratory patterns of sea birds, sea turtles, sharks and marine fish [12,13]. Thus, while coastal States are understandably concerned about the potential impact of activities in ABNJ on their immediately proximate parts of AWNJ, ecosystem connectivity means that the interests of distant coastal States may be just as implicated and impacted [14].

\subsection{Is there a principle of adjacency in the law of the sea?}

References to adjacency have featured in the development of the law of the sea. However, in most cases such references have been used in a geographic sense and not in a way that implied rights for coastal States in ABNJ. Arguably, a form of adjacency has underpinned attempts to exert greater coastal State control over waters beyond the territorial sea. For example, the Truman Proclamation is generally regarded as a key catalyst for the expansion of coastal State maritime claims beyond a narrow band of territorial sea - a phenomenon that has been termed "creeping jurisdiction" $[15,16]$. Similarly, in 1974 the ICJ found that there was a growing acceptance that coastal States had "preferential rights" to fisheries where they had a special dependence on the stocks in waters adjacent to their coasts [17]. This case was in the context of the expansion of coastal State rights over fisheries in waters beyond their territorial sea, which culminated in the EEZ.

In the case of expansion of coastal State jurisdiction, the argument that a State has a natural interest in an area of the ocean off its coast to justify extending maritime zones has not usually extended to an assertion of control beyond that area. A notable exception 
to this was the 1958 Geneva Convention on Fishing and Conservation of the Living Resources of the High Seas [18]. Article 6 acknowledged the special interest of coastal States in the productivity of living resources in the high seas adjacent to its territorial sea. The Convention allowed coastal States to initiate negotiations for measures to conserve the living resources of the adjacent high seas, and high seas fishing states could not undermine any conservation measures adopted by the coastal State. Article 7 of the Convention permitted coastal States to adopt unilateral conservation measures if negotiations with other States have not led to an agreement within 6 months. Other States were also permitted to seek negotiations for conservation measures if they had "a special interest in the conservation of the living resources of the seas in that area". These provisions therefore represent a form of preferential rights for proximate, adjacent States to areas seaward of their territorial sea limits. The Fishing Convention attracted only 39 parties. Despite suggestions that the provisions for coastal State control be continued in UNCLOS [19], the ability for unilateral action on the part of the coastal State to protect high seas resources was not repeated.

Coastal States have occasionally attempted to argue that their proximity to high seas areas should entitle them to a special interest or share in the fisheries catch from the high seas. For example, in the 1980s the United States, acting as a distant water fishing nation in the Inter-American Tropical Tuna Commission, rejected such claims on the part of Latin American States [20]. The issue also arose in the 1990s in relation to straddling and highly migratory fish stocks. Canada asserted a right to influence the rules applying to the high seas for straddling stocks, and in 1995 arrested a Spanish fishing vessel operating on the high seas for violating a moratorium on fishing turbot established in Canadian legislation $[21,22]$. This occurred at the time of the negotiation of the United Nations Fish Stocks Agreement (UNFSA) [23], and it is notable that in article 7 of that agreement, States are obliged to seek compatibility between measures on the high seas and coastal State jurisdiction. However, although coastal State interests must be taken into account, there is no priority for coastal State measures to dictate high seas measures.

Adjacency has also played a role in maritime delimitation where coastlines that are next to rather than facing one another are involved. However, in the delimitation context adjacency is used in a strictly geographical sense. 
Overall, although adjacency was an important conceptual driver of the establishment of maritime zones adjacent to the coast in UNCLOS and remains relevant in maritime boundary delimitation, the use of adjacency as a principle implying greater rights for coastal States in areas beyond national jurisdiction has generally been unsuccessful in the history of the law of the sea.

\subsection{Adjacency in law of the sea instruments}

"Adjacency" does not appear at all in UNCLOS. However, "adjacent" appears in eleven articles. ${ }^{3}$ In most cases, "adjacent" is used as a geographical descriptor to denote an area next to another, whether it be an area of sea or a coastline. However, in articles 47 and 51 the concept of "immediately adjacent neighbouring State" is introduced in the context of traditional rights. The history of the Convention reveals little discussion about this idea, but the word "immediate" was probably intended to emphasise the "adjacent" and "neighbouring" character [24].

In the UNFSA, the word "adjacent" is found in article 7, in relation to the "adjacent high seas area". In this context, "adjacent" simply reflects the fact that straddling stocks cross the EEZ boundary into an area of the high seas abutting coastal State jurisdiction. Provisions on highly migratory stocks do not refer to "adjacent" high seas areas for the reason that these stocks cover a significant range.

Thus, no explicit reference is made to adjacency as implying a greater role for coastal States over others. The closest that the Convention comes to this idea is the recognition of rights and legitimate interests of coastal States in relation to the Area in article 142. Paragraphs 1 and 2 of article 142 provide as follows:

1. Activities in the Area, with respect to resource deposits in the Area which lie across limits of national jurisdiction, shall be conducted with due regard to the rights and legitimate interests of any coastal State across whose jurisdiction such deposits lie.

2. Consultations, including a system of prior notification, shall be maintained with the State concerned, with a view to avoiding any infringement of such

\footnotetext{
${ }^{3}$ Articles 2, 15, 47, 51, 53, 55, 63 74, 76, 83, 134 of UNCLOS.
} 
rights and interests. In cases where activities in the Area may result in the exploitation of resources lying within national jurisdiction, the prior consent of the coastal State concerned shall be required.

While it might seem that article 142(2) offers guidance for how coastal State interests in the biodiversity of ABNJ might be ordered [25], the comparison is not perfect. In cases where an oil field lies beneath the continental shelf of a coastal State and the Area, it is not possible to exploit the resources of one and not the other. The requirement for coastal State consent is limited to such situations. If the resource can be exploited without risk of exploiting the resources in national jurisdiction, there is no obligation to seek coastal State consent, and the key obligation is to have due regard (Article 142(1)). The provision is intended to protect the interest of coastal States in resources already within their national jurisdiction. However, it must also be remembered that article 137 establishes that the resources of the Area may not be alienated, with article 137(2) stating in explicit terms that "[a]ll rights in the resources of the Area are vested in mankind as a whole" and "are not to be alienated", imposing a clear obligation on coastal States to that effect [26].

Provisions in UNCLOS that govern the relationship between the rights and interests of States in areas beyond the territorial sea, on the whole, tend to be balanced and reciprocal in nature [27]. The obligation to have "due regard" to the rights and interests of other States appears in many places, including in the balancing of interests in the EEZ and in the high seas $[26,27] .4$ Notably, UNCLOS does not expressly require States exercising high seas freedoms to have due regard to coastal State rights other than in relation to straddling and highly migratory fish stocks. ${ }^{5}$. Nevertheless, it has been argued that the principle of due regard is a general organising principle in the law of the sea [28] and that due regard could be considered a customary international law rule "necessarily implied in the need to ensure coexistence between the customary freedoms of the high seas, the rights in the Area, and the rights of coastal States in the EEZ and on the continental shelf" [27].

\footnotetext{
${ }^{4}$ Articles 56, 58 and 87, UNCLOS.

${ }^{5}$ Articles 87 and 116, UNCLOS.
} 
It is suggested that due regard is the most appropriate principle for balancing the rights of States in the ILBI. However, it is also recognised that the principle requires more than a restatement of principle. Rather, the principle will need to be "operationalized" [26] through criteria, priorities and mechanisms [3]. Ultimately, therefore, this means that adjacency-related concerns should be addressed through the inclusion and implementation of due regard provisions in the ILBI. In the draft texts issued to date, there has been an effort to describe the respective rights of coastal States, although arguably not in a completely satisfactory way.

\section{How can the ILBI address the rights and interests of coastal States?}

Although the law of the sea does not contain a principle that adjacent coastal States should have priority over other States in protecting biodiversity in the high seas, this does not mean that the ILBI can ignore the issue of connectivity. The Policy Brief was entirely correct to highlight the interdependence and connectivity of areas within national jurisdiction and $\mathrm{ABNJ}$, and arguably especially those parts of $\mathrm{AWNJ}$ and $\mathrm{ABNJ}$ that are directly adjacent to one another. As a practical matter, the ILBI should contain provisions to manage the intersection between the rights and obligations of States in AWNJ and ABNJ, including the use of the due regard principle [3].

In considering the scope of these provisions, it is useful to consider the various interests of States in relation to the ILBI. Although it involves generalisation, an ideal outcome for coastal States will be that a) their existing rights in AWNJ are protected; b) that activities taking place in $\mathrm{ABNJ}$ that could impact on activities and the marine environment within national jurisdiction only proceed after consultation with potentially affected States; c) that coastal States have access to mechanisms that allow them to propose measures to protect biodiversity that has an ecological and cultural connection for their people; and d) that the instrument provides a pragmatic and workable process that provides legal certainty and will not be delayed by debates over interpretation. For non-coastal or nonadjacent States, their interest is that coastal States do not impact high seas biodiversity unduly negatively, and that high seas freedoms are not undermined.

These goals are achievable without giving greater rights to coastal States in ABNJ. A variety of regional organisations already regulate activities that cross the boundary 
between $\mathrm{ABNJ}$ and $\mathrm{AWNJ}$ and it is possible to balance the interests of all States involved. Further, although not easy to realise, integration of management measures across national and international jurisdictions has the potential to improve the state of marine biodiversity. It would be ideal if it were possible to encourage more integrated management in and between such organisations, as well as across AWNJ and ABNJ through the ILBI.

The use of due regard as an organising principle can help to resolve these issues. However, in some situations the rights and obligations of coastal States can, and should, be elucidated more carefully [26]. The following sections consider issues arising from the draft text and the discussions so far.

\subsection{Identifying adjacent States}

A significant challenge is the difficulty in defining what an adjacent State is. As mentioned above, "adjacent" is usually used to identify the area next to another. However, connectivity of ocean ecosystems encompasses very large ocean spaces. Species migrate across great distances, and so the biodiversity found in one part of a region may migrate through a series of maritime zones under the jurisdiction of multiple States [29]. Similarly, activities on the high seas or in the Area may have far-reaching impacts due to ocean currents. In situations such as this, referring to the issue as "adjacency" or giving rights to "adjacent States" may be too restrictive because many States may have a reasonable interest in the activity.

Two options therefore arise. First, if adjacency remains a concept then it could be defined in the text to make it clear that the term refers to not only to the coastal State closest to the activity, but to any State significantly affected by an activity. This could include "range" States through which migratory species travel and coastal States whose jurisdiction could be impacted on by the effects of the activity. ${ }^{6}$

Second, if adjacency is not to be defined in such a way, then it will need to be used in a restricted, geographical sense to only refer to the immediately adjoining coastal State or States. Ideally, another term could be found for a situation when a broader range of

\footnotetext{
${ }^{6}$ See article 1 , Convention on Migratory Species.
} 
coastal States is being referred to. "Potentially affected States" may be sufficient in many cases. $^{7}$

A related problem is the current lack of definition of the spatial extent of ABNJ. In particular, many coastal States are yet to receive recommendations as to the outer limits of their continental shelf from the Commission on the Limits of the Continental Shelf (CLCS) under article 76(8). At the time of writing the CLCS had, since 2002, delivered 33 sets of recommendations but is faced with 84 distinct submissions with more to come [30]. Due to this backlog of work, a substantial delay in finalising the delineation of continental shelf limits beyond 200 nautical miles is anticipated. The draft text to date has been silent on the issue of uncertainty over the true extent of extended continental shelves, which inevitably has implications for both the extent of coastal State jurisdiction and ABNJ. While addressing this problem is beyond the scope of the current negotiations, the complexities and ambiguities involved will necessarily make the eventual implementation of the ILBI more challenging.

Another maritime jurisdictional issue that arises relates to the identification of the coastal State in areas of overlapping claims to extended continental shelves. Here it can be observed that overlapping submissions to the CLCS total over 3.3 million $\mathrm{km}^{2}$ [9]. The CLCS lacks the mandate to consider such claims unless the coastal States concerned allow the Commission to do so. Absent such communications from the States concerned, the CLCS will not consider submissions relating to the overlapping area [31]. In the meantime, however, who is the coastal State for the purposes of due regard consultations? One option might be that until the overlapping assertions to continental shelf rights beyond 200 nautical mile limits is settled, both interested States could be accorded the consultation rights due to the coastal State. Ideally the ILBI would provide guidance on how such problems should be dealt with, but so far the issue has not arisen in the negotiations. In this context it can also be observed that under article 83(3) of UNCLOS, pending agreement on a continental shelf boundary for the area in question, the coastal States concerned are obliged to "make every effort to enter into provisional arrangements of a practical nature" and such cooperative arrangements could address this issue.

\footnotetext{
${ }^{7}$ E.g. see article 34(2), First and Second Draft Texts.
} 


\subsection{Conceptualising adjacency/due regard}

There is utility in the parties to the ILBI negotiations fleshing out a set of principles and provisions that clarify the respective roles of States and how the rights of coastal States in AWNJ are protected from the potential impacts of activities within ABNJ and vice-versa.

Whether the term adjacency is used to capture this consideration or due regard is deployed as the overarching concept to deal with these issues, the content of the concept must be balanced, clear and practical. This view of adjacency would have the content that the parties themselves give it, would need to be consistent with existing obligations under UNCLOS and the UNFSA, and can include general principles as well as specific provisions where necessary under elements of the package.

A suggested broad approach is as follows.

1. Adjacency/due regard respects the existing balance of rights. In this sense, there would not be any assumption that coastal States have priority over other States in the management of areas beyond national jurisdiction. The counterpoint to this is that high seas activities should not have priority over coastal State rights and interests. Essentially, this involves States having due regard for the rights and interests of other States, both within and beyond national jurisdiction

2. Adjacency/due regard implies procedural rights for coastal States to be consulted when activities in $\mathrm{ABNJ}$ may impact on marine biodiversity within national jurisdiction. It may also be possible to stipulate that activities on the high seas should be managed so as to not undermine conservation and sustainability measures implemented in areas within national jurisdiction. However, this would likely not give coastal States a right of veto over the activity. This concept, based on compatibility, is discussed below at 3.3.2.

While necessarily speculative, it can be observed that is not beyond the drafters of the ILBI to ensure that it encourages global, regional and sectoral organisations to create strategies for managing impacts on biodiversity, including giving procedural rights to potentially affected coastal States in relation to matters that impact on them.

However, it must not be forgotten that coastal States also have obligations of due regard and environmental protection under UNCLOS and international law. This requires careful 
management of activities within national jurisdiction to ensure that the impacts on biodiversity in $\mathrm{ABNJ}$ are minimised. If the obligations are conceived of as mutual, applying to both coastal and flag States, this may alleviate some of the concerns that coastal States are seeking greater control.

3. The interconnectivity of ocean ecosystems encourages a regional approach to oceans management $[12,13]$. There is now compelling scientific evidence that oceans ecosystems interact over wide geographical scales. As a result, many States may be "adjacent" in relation to aspects of marine biodiversity. Therefore, the ILBI or its institutions should provide for regional cooperation so that States with interests in particular areas or initiatives can contribute to responses. This is especially important when no existing regional seas agreement exists.

At present, one key provision of the draft texts is article 4(2), which is unbracketed. This provides that " $[\mathrm{t}]$ he rights and jurisdiction of coastal States in all areas under national jurisdiction, including the continental shelf within and beyond 200 nautical miles and the exclusive economic zone, shall be respected in accordance with the Convention". Although this is statement to be interpreted in light of the Convention and so must be consistent with it, it may be possible to interpret this statement as giving some preference to coastal State interests in situations where their actions taken under the ILBI interfere in some way with coastal State interests. A preferable approach would be to provide that coastal State rights and interests must be given due regard. This would avoid any debate about the implications of draft article 4(2).

\subsection{Adjacency/connectivity and the elements of the package}

The following section comments on aspects of the adjacency/connectivity issue in relation to the different parts of the ILBI package, with a focus on the first three: marine genetic resources (MGRs), area-based management tools (ABMTs) including marine protected areas (MPAs), and environmental impact assessments (EIAs).

\subsubsection{Marine genetic resources}

Neither the negotiations nor the draft text to date, focused as they are on ABNJ, has adequately dealt with the interests of potentially affected coastal States in MGRs in a practical sense. Most significantly, there are no provisions that directly address the issue of coastal State rights to sedentary species on the continental shelf beyond 200 nautical 
miles in the context of biotechnology and bioprospecting. There are several problems with applying the sedentary species definition in art 77(4) of UNCLOS to genetic resources. Under article $77(4)$, coastal States have sovereign rights to the sedentary species of the continental shelf, which are "organisms which, at the harvestable stage, either are immobile on or under the seabed or are unable to move except in constant physical contact with the seabed or subsoil". Of particular note is the fact that organisms that may ultimately become sedentary as adults in many cases spend much of their time in the water column at larval or juvenile stages of their lifecycle, raising questions about at what point the "harvestable stage" arises [4,32]. Classifying microbes at hydrothermal vents also poses particular challenges [32].

A further challenge is that the coastal State, by virtue of its rights over sedentary species, will have sovereign rights over some, but not all, species in the same benthic ecosystem. Some species will be subject to the sovereign rights of the coastal State, others will be subject to the regime in the ILBI. This will inevitably pose tremendous difficulties for researchers in untangling the legal obligations for organisms about which they may know very little at the time of sampling. At the very least, this argues for the inclusion of an obligation to notify the coastal State when collecting samples in the vicinity of the continental shelf even if there is no intention to collect sedentary species. It is possible to conceive of other approaches that would be more protective of the coastal State interests including requiring coastal State consent before collecting samples within a certain distance of the continental shelf [10].

The closest the draft text came to this issue was draft articles 9(2) and 10(5) of the First and Second Draft Texts. Draft article 9(2) requires that where MGRs are found in AWNJ as well as ABNJ, activities shall be conducted with due regard to the rights and interests of the coastal State. In this context, it is not entirely clear what the due regard obligation would add here, other than possibly a right of consultation. It might be more appropriate to specify this if this is what is intended.

Draft article 10(5) provided for bracketed options for either prior notification and consultation or consent from the coastal State where activities might result in the utilisation of MGRs found both within and beyond national jurisdiction. This provision is less than ideal for several reasons. First, in a horizontal connectivity situation it may be impossible to know the overall distribution of a marine species that is collected in ABNJ. 
Second, it is imperfect in its application to vertical connectivity because on the continental shelf some species will be sedentary, and thus under coastal State jurisdiction for areas of outer or extended continental shelf, while all others will not be. If the intention is that the article relates to genetic resources belonging to sedentary species collected in the water column then this should be made more explicit. It would make some sense to require notification to the coastal State if MGRs are being collected in the vicinity of a State's continental shelf beyond 200 nautical miles.

\subsubsection{Area based management tools}

Two main issues arise for coastal States in relation to adjacency and ABMTs. First, there is the role that the coastal State may play in establishing ABMTs in adjacent areas of the ABNJ. Although the process for establishing ABMTs under the ILBI is not yet established, it seems that the adjacent States are to have no special role in such a process, but will have the same right as any other State to seek to establish an ABMT.

As mentioned above, the concept of "due regard" may well require special consideration of the interests of coastal States if a proposed ABMT will impact on conservation and management measures established in AWNJ due to connectivity [25](Becker-Weinberg, 2019). Whether a general reference to due regard in the ILBI will be sufficient is open to debate. The interest of coastal States in the impact of activities on AWNJ is reflected in a proposal put forward by the Pacific Small Island States at IGC3. The addition was a new paragraph in draft article 15, on international cooperation and coordination: "In cases where the proposal affects areas of high seas that are entirely surrounded by the exclusive economic zones of adjacent coastal States, the views and comments of such States shall be given particular regard." This is recognition that high seas "pockets" create particular management challenges for the surrounding coastal States $[33,34]$. This proposal walks a very fine line between asserting a special interest and a special right for adjacent, or perhaps most connected, States without actually giving coastal States additional rights. The proposal was not included in the second draft text.

The second issue is whether ABMTs should be made compatible with conservation and sustainable use measures within national jurisdiction, so as not to undermine the efforts in AWNJ. Article 7(2) of the UNFSA provides that "conservation and management measures established for the high seas and those adopted for areas under national jurisdiction shall be compatible in order to ensure conservation and management of the 
straddling fish stocks and highly migratory fish stocks in their entirety." The goal of this provision is to prevent a situation where exploitation either on the high seas or within national jurisdiction undermines conservation measures implemented elsewhere.

This idea is partially reflected in the first draft text by article $15(5)^{8}$ which provides: "measures adopted in accordance with this Part shall not undermine the effectiveness of measures adopted by coastal States in adjacent areas within national jurisdiction and shall have due regard for the rights, duties and legitimate interests of all States, as reflected in relevant provisions of the Convention. Consultations shall be undertaken to this end, in accordance with the provisions of this Part." During IGC3, this provision attracted broad support from a range of coastal States, but not universal acceptance. Despite this, the text does not appear in brackets.

The proposed article differs from article 7(2) of UNFSA in important aspects. Most significantly, the obligation to ensure measures are not undermined is not equally balanced. Under draft article 15(5) the obligation applies to measures adopted for ABNJ. Coastal States are not required to ensure that activities under their jurisdiction do not undermine the effectiveness of measures in ABMT. Of course, such States have obligations to ensure that activities under their jurisdiction do not unduly impact the marine environment in ABNJ [4]. However, coastal States may be reluctant to agree to a mutual obligation as it may lead to an argument that a coastal State could not exercise its sovereign rights, e.g. for fishing or mining, on the basis that it would undermine an ABMT established in the high seas.

A second distinction is that the last sentence of the draft article refers specifically to consultations with adjacent coastal States. An equivalent provision does not appear in article 7(2) of the UNFSA. There is a legitimate question whether this sentence is intended to limit the actions to be taken to only consultation, or whether the first sentence could be used to imply other sorts of procedural or substantive rights.

This provision does not go so far as to imply a leading role for adjacent coastal States, which was the view of "adjacency" put forward in the Policy Brief. There is nothing in the draft text that would give special rights to adjacent coastal States, and it seems that most

\footnotetext{
${ }^{8}$ See also article 15(4), Second Draft Text.
} 
States have now retreated from the idea. However, it is possible that such a provision could provide coastal States with leverage to argue for the establishment of supportive ABMTs in the ABNJ near their waters. For example, a coastal State may wish to protect benthic marine ecosystems located on their continental shelf beyond 200 nautical miles. Because coastal States only have rights in relation to the sedentary species of the shelf, in order to fully protect the ecosystems, it would be necessary to establish an ABMT for the species found in ABNJ. Although draft article 15(5) does not give coastal States any special rights regarding the areas in national jurisdiction, the intent appears to be that the measures taken to protect the marine environment in AWNJ be an important consideration.

\subsubsection{Environmental Impact Assessments}

There is much less controversy surrounding the rights of adjacent coastal States in relation to EIAs. The draft texts referred to the importance of consulting adjacent States at the stage of proposals for activities. ${ }^{9}$ Draft article 18 specifically mentioned the need to consult with adjacent coastal States and gather information about the potential impact on areas within their jurisdiction. Although many States felt that the references to adjacent States were useful, some argued for the inclusion of broader terms such as "potentially affected States".10

It will be important in this context to consider the definition of adjacent States. As already mentioned, "adjacent" appears restricted to referring to geographically abutting areas. There is a question whether a requirement to consult or notify adjacent States will be broad enough to include all coastal States that may be impacted by a proposed activity. Therefore, using "potentially affected States" will be preferable if the intention is to take into account the connectivity of the ocean and the breadth of possible impacts. On the other hand, limiting obligations to focus on geographically adjacent States makes the process much clearer for the entity undertaking the EIA as the adjacent State will be easier to identify than all potentially affected States.

The EU, rather than referring to adjacent States, suggested that draft article 18(2)(h) should provide that the proposal will include information on consultations, if any, with

\footnotetext{
${ }^{9}$ Draft articles 17(4) re ABMTs and 34 re EIAs

${ }^{10}$ E.g. EU proposal, Conference Room Paper EIA/CRP.3.
} 
"all States, including the most potentially affected States, any States with a continental shelf subjacent or maritime area adjacent to any proposed marine protected area and States that carry out human activities, including economic activities in the area". This is an example of a very broad expectation of consultation which would pose fairly high procedural barriers if the proponents of activities were to conduct such broad consultations even before a proposal is submitted.

Finally, it is interesting to note that at IGC 3 the PSIDS and the Philippines suggested that, where a proposal relates to high seas pockets, the views and comments of the surrounding States shall be of particular regard. ${ }^{11}$ This proposal was not adopted in the second draft text.

\section{Conclusion}

Coastal States are naturally concerned about the impact of activities in the high seas and the Area on biodiversity in AWNJ, especially given the connectivity issues outlined above. However, other non-proximate States are likewise connected and have legitimate interests as does the international community as a whole. It is unlikely that the international community will accept that geographically proximate States should have some sort of greater rights or control over such activities in ABNJ. Instead, the interconnectivity of biodiversity in the oceans requires coordination and cooperation across the extent of ecosystems. While the BBNJ negotiations have tended to focus primarily on activities beyond national jurisdiction, this seems to downplay the relationship between activities in all parts of the oceans.

Ideally, the ILBI would clearly set out the principles and processes by which the relationship between areas within and beyond national jurisdiction would be managed. If this is too difficult to do in the treaty itself, then the COP or other institution created by the ILBI could be given competence to facilitate coordination across all maritime zones.

How this set of principles develops is up to States themselves as the negotiations are ongoing. However, any approach should be based on the existing balance of rights and obligations under UNCLOS plus use a problem-solving approach to particular issues that

\footnotetext{
${ }^{11}$ Conference Room Paper EIA/CRP.3.
} 
might arise under the elements of the treaty. Due regard seems to be the most suitable general principle to support this balancing approach, but States rightly have accepted that some more specific provisions will be needed in parts of the ILBI to set out the rights and obligations in relation to adjacent coastal States.

\section{References}

[1] United Nations, 2019, Intergovernmental Conference on Marine Biodiversity of Areas Beyond National Jurisdiction. https://www.un.org/bbnj/ (accessed 18 September 2019).

[2] DC. Dunn, G.O. Crespo, M. Vierros, D. Freestone, E. Rosenthal, S. Roady, A. Alberini, A.L. Harrison, A. Cisneros, J.W. Moore, M.R. Sloat, Y.Ota, R. Caddell, P.N. Halpin, Adjacency: How legal precedent, ecological connectivity, and Traditional Knowledge inform our understanding of proximity. Policy brief, Nereus Program (2017). https://nereusprogram.org/reports/policy-brief-adjacency-how-legal-precedentecological-connectivity-and-traditional-knowledge-inform-our-understanding-ofproximity/ (accessed 12 July 2018).(Policy Brief)

[3] T. Treves, Principles and Objectives of the Legal Regime Governing Areas beyond National Jurisdiction; in: E.J. Molenaar and A.G. Oude Elferink (eds.) The International Legal Regime of Areas beyond National Jurisdiction: Current and Future Developments Leiden: Martinus Nijhoff, 2010, 7-25.

[4] J. Mossop, The Continental Shelf beyond 200 Nautical Miles: Rights and Responsibilities, Oxford: Oxford University Press, 2016.

[5] Draft text of an agreement under the United Nations Convention on the Law of the Sea on the conservation and sustainable use of marine biological diversity of areas beyond national jurisdiction A/Conf.232/2019/6 (First Draft Text)

[6] Revised draft text of an agreement under the United Nations Convention on the Law of the Sea on the conservation and sustainable use of marine biological diversity of areas $\begin{array}{llll}\text { beyond national jurisdiction, } & 27 & \text { November }\end{array}$ https://www.un.org/bbnj/sites/www.un.org.bbnj/files/revised draft text a.conf .232. 2020.11 advance unedited version.pdf (accessed 28 November 2019) (Second Draft Text).

[7] PSIDS Submission to the Second Meeting of the Preparatory Committee for the Development of an international legally binding instrument under the United Nations Convention on the Law of the Sea on the conservation and sustainable use of marine biological diversity of areas beyond national jurisdiction (BBNJ PrepCom), https://www.un.org/depts/los/biodiversity/prepcom files/rolling comp/PSIDS secon d.pdf (accessed 21 November 2019).

[8] Xinmin M., China and the UNCLOS: Practices and Policies, Chinese Journal of Global Governance 5 (2019) 1-20. 
[9] C.H. Schofield and L. Bernard (forthcoming). Disputes Concerning the Delimitation of the Continental Shelf Beyond 200 M, in: T. Heidar (ed.), New Knowledge and Changing Circumstances in the Law of the Sea, Reykjavik: Law of the Sea Institute of Iceland.

[10] J. Mossop, The relationship between the continental shelf regime and a new international instrument for protecting marine biodiversity in areas beyond national jurisdiction, (2018) 75 ICES Journal of Marine Sciences 75 (2018) 444-450.

[11] B.C. O’Leary, C.M. Roberts, 2018. Ecological connectivity across ocean depths: Implications for protected area design, Global Ecology and Conservation 15, e00431. https://dpi.org/10.1016/j-gecco.2018.e00431 (2018).

[12] E. Popova, A. Bladon, E.Y. Mohammed, D. Vousden and W. Sauer, 2019, So far, yet so close: ecological connectivity between $\mathrm{ABNJ}$ and territorial waters, International Institute for Environment and Development (IIED), Briefing, February 2019, https://pubs.iied.org/pdfs/17500IIED.pdf (accessed 18 September 2019).

[13] D.P. Costa, G.A. Breed, P.W. Robinson, New Insights into Pelagic Migrations: Implications for Ecology and Conservation, Annual Review of Ecology, Evolution and Systematics 43 (2012) 73-96.

[14] A-L. Harrison et al, The political biogeography of migratory marine predators, Nature Ecology and Evolution, 2 (2018) 1571-1578.

[15] B. Kwiatkowska, Creeping Jurisdiction Beyond 200 Miles in Light of the 1982 Law of the Sea Convention and State Practice, Ocean Development and International Law 22 (1991) 153-187.

[16] J.A. Roach and R.W. Smith, Excessive Maritime Claims, $3^{\text {rd }}$ edition. Leiden/Boston: Martinus Nijhoff Publishers, 2012.

[17] Fisheries Jurisdiction (UK v Iceland) (Judgment) ICJ Reports 1974, 3-44.

[18] Convention on Fishing and Conservation of the Living Resources of the High Seas (opened for signature 29 April 1958, entered into force 20 March 1966) 559 UNTS 285.

[19] J.L. Jacobson, Bridging the Gap to International Fisheries Agreement: A Guide for Unilateral Action, San Diego Law Review 9 (1971-1972) 454-490.

[20] J. Van Dyke and S. Haftel, Tuna Management in the Pacific: An Analysis of the South Pacific Forum Fisheries Agency, University of Hawaii Law Review 3 (1981) 1-65.

[21] A. Schaefer, 1995 Canada-Spain Fishing Dispute (The Turbot War), Georgetown International Environmental Law Review 8 (1996) 437-449.

[22] O. Akiba, International Law of the Sea: The Legality of Canadian Seizure of the Spanish Trawler (Estai), Natural Resources Journal 37 (1997) 809-828.

[23] Agreement for the Implementation of the Provisions of the United Nations Convention on the Law of the Sea of 10 December 1982 relating to the Conservation and Management of Straddling Fish Stocks and Highly Migratory Fish Stocks (opened for signature 4 December 1994, entered into force 11 December 2001) 2167 UNTS 88 (UNFSA).

[24] S.N. Nandan and S. Rosenne (eds), United Nations Convention on the Law of the Sea 1982: A Commentary Volume II, Martinus Nijhoff, 1993. 
[25] V. Becker-Weinberg, Preliminary Thoughts on Marine Spatial Planning in Areas beyond National Jurisdiction, in: D. Freestone (ed) Conserving Biodiversity in Areas beyond National Jurisdiction, Brill Nijhoff, Leiden, 2019, pp. 85-103.

[26] A. Oude Elferink, Coastal States and MPAs in ABNJ: Ensuring Consistency with the LOSC, International Journal of Marine and Coastal Law 33 (2018) 437-466.

[27] T. Treves, 'Due regard' Obligations under the 1982 UN Convention on the Law of the Sea: The Laying of Cables and Activities in the Area, International Journal of Marine and Coastal Law 34 (2019) 167-194.

[28] B.H. Oxman, The Principle of Due Regard; in: ITLOS The Contribution of the International Tribunal for the Law of the Sea to the Rule of Law 1996-2016, Leiden: Brill/Nijhoff, 2018, 108-116.

[29] D.C. Dunn et al, The importance of migratory connectivity for global ocean policy, $\begin{array}{llllll}\text { Proceedings } & \text { Royal } & \text { Society } & \text { B } & 20191472 & \text { (2019). }\end{array}$ https://dx.doi.org/10.1098/rspb.2019.1472.

[30] United Nations, Commission on the Limits of the Continental Shelf, 2019, Submissions and Recommendations, https://www.un.org/Depts/los/clcs new/commission submissions.htm (accessed 21 November 2019).

[31] United Nations, Commission on the Limits of the Continental Shelf, 2008, Rules of Procedure of the Commission on the Limits of the Continental Shelf, Annex I, https://www.un.org/Depts/los/clcs new/clcs home.htm.

[32] C.H. Allen, Protecting the Oceanic Gardens of Eden: international law issues in deepsea vent resource conservation and management, Georgetown International Environmental Law Review 13 (2001) 563-660.

[33] Q. Hanich, Regional fisheries management in ocean areas surrounding Pacific Islands States, in: H. Terashima (ed), Proceedings of the International Seminar on Islands and Oceans, Tokyo, Ocean Policy Research Foundation, 2010, pp. 195-212.

[34] E. Meltzer, Global overview of straddling and highly migratory fish stocks: the nonsustainable nature of high seas fisheries, Ocean Development and International Law 25 (1993) 255-344. 